\title{
УКРАЇНСЬКО-НІМЕЦЬКІ ПАРЕМІОЛОГІЧНІ ПАРАЛЕЛІ
}

Колоїз Ж. В. Українсько-німецькі пареміологічні паралелі.

У статті йдеться про українсько-німецькі пареміологічні паралелі, з'ясовуються їх структурно-семантичні та етнолінгвістичні особливості. Аналізується співвідношення національної мови й культури через взаємодію власне мовних та етнокультурних чинників, через вплив на мовну структуру побуту, звичаїв, обрядів, вірувань, менталітету етносу.

Ключові слова: паремія, пареміологічна одиниця, відповідник, структура, семантика, етнолінгвістичні особливості.

Колоиз Ж. В. Украинско-немецкие паремиологические параллели.

В статье рассматриваются украинско-немецкие паремиологические параллели, исследуются их структурно-семантические и этнолингвистические особенности. Анализируется соотношение национального языка и культуры через взаимодействие собственно лингвистических и этнокультурных факторов, через влияние на языковую структуру быта, обычаев, обрядов, верований, менталитета этноса.

Ключевые слова: паремия, паремиологическая единица, соответствие, структура, семантика, этнолингвистические особенности.

Koloiz Zh. V. Ukrainian-German paremiological parallels.

The article deals with the Ukrainian-German paremiological parallels, their structural-semantic and ethno-linguistic features are cleared up. The relation between national language and culture is analyzed through interaction of lingual and ethno-cultural factors, via the influence over the language structure of everyday life, customs, rituals, beliefs, ethnic group mentality.

Key words: paremiya, paremiological unit, equivalent, structure, semantics, ethnolinguistic features.

У сфері пареміології, як відомо, найбільш яскраво представлено національний спосіб світосприйняття, репрезентовано національний світ, у якому злиті воєдино людина та історичне природне оточення, що впливає на соціальну психологію етносу, формує національний характер та визначає спрямованість його практичної діяльності.

Дослідження паремій у лінгвокультурологічному аспекті сприяє виявленню специфічних рис тієї чи тієї нації, зумовлених особливостями світосприйняття, системою моральних вимог, норм, цінностей і принципами виховання. Ці одиниці утворюють одну 3 семіотичних підсистем, що забезпечують процес повноцінної комунікації носіїв однієї мови. Як справедливо зауважує В Телія, «сама можливість постановки проблеми про взаємодію мови і культури, 
зокрема про корелятивне взаємовідношення одиниць фразеології (у широкому витлумаченні, тобто з урахування і так званих прислів'їв, приказок і т. ін. - Ж. К.) та концептосфери культури, у якій би з версій лінгвокультурологічного аналізу вона не висувалася, зумовлена припущенням про високу ймовірність здатності суб'єктів мови як суб'єктів культури втілювати в мовленнєво-мисленнєву діяльність знання, пов'язані зі сферою осмислення світу людиною» [7, с. 19]. Виявлення та опис мовних одиниць, які в дискурсивних практиках зберігають зв' язок з концептами культури, служать засобом презентації тих чи тих фрагментів їх смислу - важливий аспект усіх лінгвокультурологічних розвідок. Актуальність таких наукових доробків визначається передусім увагою до проблем національного самоусвідомлення, самовираження, співвідношення мови і духовної культури.

Мета нашої наукової розвідки полягає в тому, аби дослідити українсько-німецькі пареміологічні паралелі, з'ясувати структурносемантичні та етнолінгвістичні особливості пареміологічних одиниць.

Про паремії, або так звані прислів'я та приказки, протягом ряду століть написано чимало. Проте справжній наукових підхід до дослідження пареміологічних утворень пов' язують із другою половиною XIX століття, зокрема 3 ім'ям Олександра Потебні. Відтоді ці одиниці активно розроблялися як у вітчизняному, так i в зарубіжному мовознавстві (Г. Благова, Т. Бочина, С. Величко, І. Голубовська, В. Жайворонок, О. Мерзликіна, В. Мокієнко, О. Наконечна, Т. Ніколаєва, Н. Пашенько, Г. Пермяков, В. Пирогов, В. Прутчикова, Г. Садова, Л. Скрипник, 3. Тарланов, Н.Шарманова та ін.). Проте, незважаючи на значні досягнення в цій царині, у вивченні паремій залишається низка проблемних питань, суперечливих тверджень, зокрема й тих, що стосуються не лише походження, структурно-семантичних, функціонально-стилістичних, прагматичних особливостей. Адже новим i досить актуальним у сучасній лінгвістиці постає питання про виокремлення в мовній системі пареміологічного рівня, що обіймає два великі мовні масиви - власне паремійний та афористичний. Одиниці пареміології, навіть найменші та найпростіші за формою, являють собою тексти, тобто вербальні конструкції, які можуть використовуватися самостійно, виступати знаками й одночасно типовими моделями різних типових ситуацій. Наприклад: укр. $y_{c i}$ дороги ведуть до Puмy і нім. Alle Wege führen nach Rom (пор. також: Alle Gewässer fließen ins Meer, тобто Усі води течуть у море); укр. 
Краще пізно, ніж ніколи і нім. Besser spät als niemals; укр. Хто посіє вітер, пожне бурю і нім. Wer Wind sät, wird Sturm ernten; укр. Anетит з їою прибуває і нім. Der Appetit kommt beim Essen; укр. Не все то золото, щьо блищить і нім. Es ist nicht alles Gold, was glänzt тощо.

Думка про те, що мова - вагома частина етнокультури, $\epsilon$ загальновизнаною. І незалежно від того, чи то мова сама проходить через «канали культури», чи то, навпаки, культура проходить через «мовні канали», цілком очевидно: звичаї і традиції впливають на комунікативну систему етносу, а культурні цінності й вірування частково створюють етномовну реальність. Пор., наприклад: нім. August ohne Feuer macht das Brot teuеr (дослівно: Серпень без тепла - хліб втридорога); Adel liegt im Gemüte, nicht im Geblüt (дослівно: Благородність не в крові, а в xарактері); Ein gut Gemüt ist besser als ein gut Geblüt (дослівно: Добре серие краще за добру кров); Allen Leuten recht getan ist eine Kunst, die niemand kann (дослівно: Усім людям догодити -мистецтво, яке нікому не nid силу); Alles Gute kommt von oben (дослівно: Усе добре приходить зверху); Das Wasser ist König, sogar das Feuer hat Angst vor dem Wasser (дослівно: Вода - король, навіть вогонь ї боїться); Ein Staat ohne Recht ist wie ein Leib ohne Seele (дослівно: Держава без права, щчо тіло без душі); Ein groher Gast ist niemand Last (дослівно: Веселий гість нікому не тягар); Einem zufriedenen Herzen scheint die Sonne überall (дослівно: Задоволеному серияю всюди світить сонце); Ein reines Gewissen, ein gutes Ruhekissen (дослівно: Чиста совість - хороша подушка); Gutes Futter, gute Butter (дослівно: Гарний корм - гарне масло) тощо.

Будь-яка мова загалом так чи так відбиває етнокультурні стереотипи, породжені національною специфікою людського світосприймання. Такі мовні явища входять у коло етнолінгвістичних студій, оскільки лінгвістика як наука вивчає передусім співвідношення національної мови й культури через взаємодію власне мовних та етнокультурних чинників i 3 огляду на їхню роль у функціонуванні та еволюції тієї чи тієї мови. Інакше кажучи, етнолінгвістичний аспект наукових студій передбачає вивчення результатів впливу на мовну структуру побуту, звичаїв, обрядів, вірувань, загальної культури й менталітету етносу.

Диференційними ознаками пареміологічних одиниць будь якої мови виступають: повна чи відносна синтаксична завершеність та сентенційність або еквівалентність логічному судженню, що відображає оцінно-етичну інформацію. Наприклад: укр. Кожен край має свій звичай і нім. Andere Länder, andere Sitten (дослівно: Інші краӥни, інші звичаі); укр. 
Терпи, козаче, отаманом будеш і нім. Geduld bringt Rosen (дослівно: Терпіння приносить троянди); укр. Що маємо - не дбаємо, а втративши, плачем і нім. Den Brunnen schätzt man erst dann, wenn es kein Wasser mehr gibt (дослівно: Цінність колодязя пізнаємо тоді, коли в ньому більше немає води); укр. Шлях до серчя чоловіка лежить через шлунок і нім. Die Liebe geht durch den Magen (дослівно: Любов приходить через илунок); укр. На помилках учаться і нім. Durch Fehler wird man klug (дослівно: Через помилки стають розумними) тощо. I в українській, і в німецькій мовах такі логічні судження мають характер а) ствердження або б) заперечення. Наприклад: а) укр. Без гетьмана військо гине; Без перевесла сніп - солома; До булави треба голови; У гурті й каша добре їсться; Гуртом добре й батька бити; Де чорт не зможе, там баба поможе; Баба з возу - кобилі легше; Жіноча річ - кочерга та піч; Біда біду тягне; Нещастя ходить парами; Сліпий казав: «Побачимо»; Це ще вилами по воді писано; нім. In der Not schmeckt jedes Brot (дослівно: У біді будь-який хліб смачний); Im Dunkeln ist gut munkeln (дослівно: $У$ темноті легко говорити потайки); Ist der Wein im Manne, ist der Verstand in der Kanne (дослівно: Вино в людині-розум у графині); Dummheit und Stolz wachsen auf einem Holz (дослівно: Дурість i гордість ростуть на одному дереві); Unverhofft kommt oft (дослівно: Несподіване приходить часто); Kluge Leute fehlen auch (дослівно: Мудрі люди також помиляються) тощо; б) укр. Криком дуба не зрубаєш; Ночвами моря не перепливеш; Пальцем потопу не заставити; Бабу і чорт не змудрує; Без муки нема науки; Не йде наука без бука; Печені голуби не летять до губи; Добре ковадло не боїться молотка тощо; нім. Hitzig ist nicht witzig (дослівно: Запальний - не розумний); Die Krippe geht nicht zum Ochsen (дослівно: Ясла до бика не ходять); Sei nicht faul, die Krippe kommt nicht zum Maul (дослівно: Не лінуйся, ясла самі до рота не підійдуть); Einem trauen ist genug, keinem trauen ist nicht klug (дослівно: Одному довіряти - добре, нікому не довіряти - нерозумно); Aufgeschoben ist nicht aufgehoben (дослівно: Відкласти не означає відмінити); Beredter Mund geht nicht zugrund (дослівно: 3 красномовним язиком не пропадеш); Mit Zank und Streit kommt man nicht weit (дослівно: 3 суперечкою $і$ чварами далеко не nidew); Tanz vor dem Tode ist nicht in der Mode (дослівно: Танці перед смертю не в модi). Заперечна модальність здебільшого забезпечується заперечними частками, відповідно, не - для україномовних паремій i nicht - для німецькомовних, що стосуються переважно предиката: не зрубаєш, не перепливеш, не заставити і т. ін.; nicht witzig, nicht faul, 
kommt nicht, nicht klug, nicht aufgehoben і т. ін. Але не тільки: Nicht jeder, der einen Bart trägt, ist ein Philosoph (дослівно: Не кожний, хто носить бороду, є філософом (пор.: укр. Мудрість в голові, а не в бороді; Борода не робить мудрим чоловіка; Честь не вусам і бороді, а розуму в голові; рос. Не за бороду - за ум жалуют; Борода козлу не замена); Nicht jeder Stein ist ein Edelstein (дослівно: Не кожний камінь дорогоцінний (пор.: укр. Не все те золото, щэо блищить; Блищить, як злото, а всередині болото; Буває, що й черепок блищить; Не все те добре, що смакує; Не все те козак, що списа має).

Подекуди в німецькомовних пареміях заперечення досягається за рахунок частки kein $(н i, \mu e)$, що в україномовних відповідниках репрезентується модальним словом немає, рідше - часткою - не: Keіn Haus ohne Maus (дослівно: Немас хати без мишей); Kein Feuer ohne Rauch (дослівно: Немає диму без вогню); Kein Vorteil ohne Nachteil (дослівно: Немає переваг без недоліків); Versehen ist kein Vergehen (дослівно: Помилка - не злочин); Begangene Tat leidet keinen Rat (дослівно: Здійснений учинок порад не потребує); Der Vorsatz allein sprengt keinen Stein, де keinen Stein - ні каменя (жодного каменя) (дослівно: Тільки намірами жодного каменя не підірвеш). Однак такі частки в німецькомовних зразках можуть бути й відсутні, попри те, що український відповідник маніфестує заперечну модальність, наприклад: Junges Blut hat Mut (дослівно: Молода кров має мужність (пор.: укр. Молодість не знає страху); Der beste Baum bringt wohl auch eine krüppelige Frucht (дослівно: I найкраще дерево приносить зіпсовані плоди (пор.: укр. У родині не без виродка). І україномовні, і німецькомовні паремії репрезентують чи то пряму, чи то зумовлену закономірність: укр. Швець, знай своє шевство, а в кравецтво не лізь; До біди доріг багато, а від біди й стежки немає; Не так хутко загоїться, як біда скоїться; Упросилися злидні на три дні, а чорт їх довіку викишкує; Коли жінка каже лихо, не зачіпай ї̈ стиха; Коли не пиріг, то й не пирожися, коли не тямиш, то й не берися; Як не коваль, то й рук не погань; нім. Im Becher ersaufen mehr als im Meer (дослівно: У вині тоне більше людей, ніж у морі); Nach Faulheit folgt Krankheit (дослівно: За лінощами приходить хвороба); Kunst bringt Gunst (дослівно: Мистецтвво знаходить собі покровителів); Die Karte und die Kanne macht manchen zum armen Maпnе (дослівно: Карти $i$ чарка доводять до бідності); Ist der Bauch voll, ist der Mensch toll (дослівно: Якщо живіт повний, людина біситься); Rast' ich, so rost' ich (дослівно: Якщо я відпочиваю, то я ржавію); Ein Lamm flieht, wenn's den Geier

(c) ж. В. Колоїз, 2012. 
sieht (дослівно: Ягня рятується втечею, коли побачить шуліку). Оформляються у вигляді порад, настанов, рекомендацій, підказаних досвідом і певною життєвою ситуацією. Наприклад: укр. Дурневі завжди щастить і нім. Die dümmsten Bauern haben die dicksten Kartoffeln (дослівно: У найдурніших селян найбільша картопля); укр. Кашу маслом не зіпсуєш і нім. Doppelt genäht halt besser (дослівно: Зиите двічі краще тримається); укр. Кінець - ділу вінець і нім. Ende gut, alles gut (дослівно: Кінець добрий, усе добре); укр. Хто високо літає, той низько падає і нім. Hochmut kommt vor dem Fall (дослівно: Зарозумілість приходить перед падінням); укр. Стислість - сестра таланту і нім. In der Kürze liegt die Würze (дослівно: У лаконічності вся правда); укр. Зустрічають по одягу і нім. Kleider Machen Leute (дослівно: Одяг робить людей); укр. Маленьке, та важненьке і нім. Klein, aber fein (дослівно: Маленький, але гарний); укр. Маленькі діти не дають спати, а великі - жити і нім. Kleine Kinder - kleine Sorgen, große Kinder - große Sorgen (дослівно: Маленькі діти - маленькі клопоти, великі діти - великі клопоти); укр. Ранок покаже і нім. Kommt Zeit, kommt Rat (дослівно: Рішення прийде з часом); укр. Краще жахливий кінець, ніж жах без кіния і нім. Lieber ein End emit Schrecken, als ein Schrecken ohne Ende (дослівно: Краще кінецьь зі страхом, ніж страх без кіния); укр. На брехні далеко не заїдеш і нім. Lügen haben kurze Beine (дослівно: У брехні короткі ноги) тощо. Зміст проілюстрованих паремій відображає різні елементи денотативної ситуації, має двоплановий характер: пізнавальний, або позамовний, i субстанційний, або мовний. Пізнавальний зміст думки, вираженої пареміологічною одиницею, існує у свідомості мовців як інтенція, а субстанційний - як відповідна сентенція.

Структурно пареміологічні одиниці обох мов співвідносяться як 3 простим, так i зі складним (чи то елементарним, чи то неелементарним) реченням: укр. Очі-дзеркало душі і нім. Das Auge ist der Seele Spiegel; укр. Від малої іскри великий пожар і нім. Aus einem Funken wird oft ein großes Feuеr; укр. Із нічого не буде нічого і нім. Aus nichts wird nichts; укр. Кінець діло вінчає і нім. Ausgang gibt den Taten ihre Titel; укр. Скрипуче дерево два віки стоїть і нім. Der Baum, der oft knarrt, bricht nicht leicht (дослівно: Скрипуче дерево не легко ламається); укр. Гни дерево, поки гнеться і нім. Das Bäuтchen ти $\beta$ man biegen, solange es jung ist (дослівно: Деревце треба гнути, поки воно молоде); укр. Дерево пізнається за плодами і нім. Dеп Baum erkennt man an den Früchten; укр. Гора з горою не сходиться, а людина 
з людиною зійдеться і нім. Berg und Tal kommen nicht zusammen, wohl aber die Menschen; укр. За чужим хмелем щз-небудь змелем і нім. Es ist gut, den Schnitt am fremden Tuch zu lernen (дослівно: Добре вчитися кроїти на чужому матеріалі); укр. Поки не намучишся, доти не научишся і нім. Ein Gelger zerreißt viel Saiten, eh' er Meister wird (дослівно: Скрипаль чимало струн порве, поки майстром стане); укр. Як постелеш, так і виспишся і нім. Bettest du dich gut, so liegst du gut (дослівно: Постелеш добре, добре лежатимеш) тощо. Це переважно двочленні речення, здебільшого заримовані. Наприклад: укр. Не розумний тим Денис, щзо великий має ніс; Шовкова борідка, а розуму рідко; Від розкошів кучері в'ються, а від журби січуться; Бідному Савці нема долі ні на печі, ні на лавиі: на печі б’ють, а на лавці січуть; Cтариі не родяться, а робляться; нім. Der Gast ist wie der Fisch, er bleibt nicht lange frisch (дослівно: Гість, як риба: свіжим залишається недовго); Alt genug und doch nicht klug (дослівно: Досить старий, та не розумний); Borgen macht Sorgen (дослівно: Борги завдають клопотів); Hinter dem Gitter schmeckt auch Honig bitter (дослівно: $3 a$ тратами і мед гіркий); Jedes Warum hat sein Darum (дослівно: Кожне «чому»має своє «тому»); Es ist kein Baum so stark, die Axt dringt ihm ins Mark (дослівно: Яким би міцним дерево не було, сокира прорубає йому стержень). Такі пареміологічні одиниці відзначаються семантичною неоднорідністю: в одних із них зберігається конкретна предметність, пряма номінативність значення, що випливає із суми значень слів-компонентів, а в інших - розвивається ще й другий семантичний план - узагальнено-метафоричне, переносне значення, яке безпосередньо не формується значенням їхніх складників: укр. Вечір день хвалить і нім. Man soll den Tag nicht vor dem Abend loben (дослівно: Не варто хвалити день до вечора); укр. Хто рано встає, тому Бог дає і нім. Morgenstund' hat Gold im Mund (дослівно: У раннього часу золото в устах); укр. Біда всього навчить і нім. Not macht erfinderisch (дослівно: Нужда робить винахідливим); укр. Без труда нема плода і нім. Ohne Fleiß kein Preis (дослівно: Без старання не буває нагороди); укр. Слово - срібло, мовчання - золото і нім. Reden ist Silber, Schweigen ist Gold (дослівно: Говорити - срібло, мовчання - золото); укр. Полову їсть, а фасон тримає і нім. Samt am Kragen, hunder im Magen (дослівно: Оксамит на коміриі, голод у илунку); укр. Чужа біда за иукор і нім. Schadenfreude ist die beste Freude (дослівно: Зловтіха - найкращий вид радості); укр. У тихому болоті чорти водяться і нім. Stille Wasser sind tief (дослівно: Tuхі 
води глибокі); укр. Повторення - мати навчання і нім. Übung macht den Meister (дослівно: Вправи роблять умільия); укр. Де двоє б’ються, третій не втручайся і нім. Wenn zwei sich streiten, freut sich der Dritte (дослівно: Коли двоє сваряться, радіє третій); укр. Не рубай сук, на якому сидии і нім. Wer im Glashaus sitzt, sollte nicht mit Steinen werfen (дослівно: Хто сидить у скляному домі, тому не слід кидати каміння); укр. Хто не ризикує, той не n'є шампанського і нім. Wer nicht wagt, der nicht gewinnt (дослівно: Хто не відважний, той не виграє); укр. Хто сміється, тому не минеться і нім. Wer viel gastiert, hat bald quittiert (дослівно: Хто багато пирував, скоро поплатиться); укр. Любиш кататися, люби й саночки возити і нім. Wer will haben, der тиß graben (дослівно: Хто хоче мати, той повинен $і$ копати); укр. На чиєму возі сиджу, того й пісню співаю і нім. Wes brot ich ess', des Lied ich sing' (дослівно: Чий хліб я ӥм, того й пісню співаю); укр. Жити, як вареник у маслі і нім. Wie eine Made im Speck leben (пор. дослівно: Жити, як черв'як у салі); укр. Дивитися, як баран на нові ворота і нім. Wie ein Schwein vor dem Uhrwerk stehen (дослівно: Дивитися, як свиня на часовий механізм); укр. У семи няньок дитина без носа і нім. Zu viele Köche verderben den Brei (дослівно: Занадто багато поварів тільки псують кашу) тощо.

Впадає в око те, що і в українській, і в німецькій мовах доволі часто пареміологічні одиниці організовані за подібними структурними моделями, зокрема це стосується й паремій, співвідносних зі складнопідрядним реченням, у яких так звана підрядна частина займає препозицію, наприклад: укр. Що з возу (мосту) впало, те пропало; Що має бути, того не минути; Що в молодості навчишся, те на старість як знайдеш; Що знаєш (умієш), те за плечима не носити; Що горить, те не мерзне; Що написано пером, того не витягнеш $i$ волом; Хто давнє пом'яне, той лиха не мине; Хто спішить, той людей смішить тощо; нім. Was sein soll, schickt sich wohl (дослівно: Що має бути, те і станеться); Was ich denk' und tu', trau ich auch andern zu (дослівно: Що я думаю і роблю, того очікую і від інших); Wonach einer ringt, danach ihm gelingt (дослівно: За що борюся, того добиваюся); Wer neidet, der leidet (дослівно: Хто заздрить, той страждає); Wer will was gelten, der komme selten (дослівно: Хто хоче, щуоб його цінували, нехай часто не приходить) тощо. Причому деякі паремії структурно варіюються: Was du heute kannst besorgen, das verschiebe nicht auf morgen (дослівно: Що можна зробити сьогодні, не відкладай на завтра); Verschiebe nicht auf morgen, was du heute kannst besorgen 
(дослівно: Не відкладай на завтра те, що можна зробити сьогодні). Примітними $\epsilon$ пареміологічні конструкції 3 так званими порівняльними відношеннями (краще.., ніж): укр. Краще з розумним згубити, ніж з дурнем знайти; Краме яйще сьогодні, ніж курка завтра; нім. Besser zweimal messen, als einmal vergessen (дослівно: Краще двічі виміряти, ніж один раз забувати); Besser zehn Neider denn ein Mitleider (дослівно: Краще десять заздрісників, ніж один співчутливець); Besser geleiert als gefeiert (дослівно: Краще грати на шарманиі, ніж нічого не робити); Besser ein Esel, der mich tragt, als ein Pferd, das mich schlagt (дослівно: Краще осел, який мене несе, ніж кінь, який мене б’'); Besser eine Stunde zu früh, als eine Minute zu spat (дослівно: Краще на годину раніше, ніж на хвилину пізніше); Besser zи früh als zи spat (дослівно: Краще занадто рано, ніж занадто пізно); Besser zweimal messen als einmal vergessen (дослівно: Краще двічі виміряти, ніж один раз відрізати).

Досить продуктивною в обох мовах $є$ модель на зразок укр. який $(-a,-e) . .$, такий $(-a,-e)$ і нім. wiе..., sо: укр. Який сусіда, така й бесіда; Яка гребля, такий млин; Який батько, такий син; Яка хата, такий тин; Яке волокно, таке й полотно; Яке коріння, таке й насіння і т. ін.; нім. Wie der Herre, so's Gescherre (дослівно: Який господар, така й упряж); Wie die Mache, so die Sache (дослівно: Яка робота, така і річ); Wie der Hall, so der Stall (дослівно: Який звук, така й конюшня); Wie der Baum, so die Birn' (дослівно: Яке дерево, така і груша); Wie die Frau, so die Dirn' (дослівно: Яка жінка, така й донька) тощо. Німецьке wie..., so іноді співвідносне з українським як..., так: Wie gewonnen, so zerronnen (дослівно: Як нажито, так і прожито); Wie du mir, so ich dir (дослівно: Як ти мені, так я тобі).

В основі багатьох пареміологічних одиниць лежить антитеза, що забезпечується не лише відповідними протиставними смисловими відношеннями, але й лексичними як загальномовними, так $\mathrm{i}$ контекстуальними антонімами: укр. Добро пушить, а лихо сушить; Сьогодні пан, а завтра пропав; Сьогодні густо, а завтра пусто; нім. Неите rot, morgen tot (дослівно: Сьогодні червоний, завтра мертвий); Hеиtе Kaufmann, morgen Bettelmann (дослівно: Сьогодні купещь, завтра старещь); Heute zechen, morgen nichts zи brechen (дослівно: Сьогодні пирувати, завтра нічого жувати); Heute stark, morgen im Sarg (дослівно: Сьогодні сильний, завтра в гробу) Erst der Magen, dann der Kragen (дослівно: Спочатку шлунок, потім комірець); Erst die Last, dann die Rast (дослівно: Спочатку ноча, потім відпочинок); Erst denken, dann lenken (дослівно: 
Спочатку подумай, потім керуй); Erst besinnt, dann beglnn's (дослівно: Спочатку подумай, потім починай); Erst prob's, dann lob's (дослівно: Спочатку попробуй, потім хвали) тощо.

Незважаючи на те, що у складі пареміологічних одиниць будь-якої мови національні елементи поєднуються 3 інтернаціональними (пор., наприклад, біблеїзми: Der Mensch lebt nicht vom Brot allein - Не хлібом єдиним живе людина; Man sieht den Splitter im fremden Auge, im eignen dem Balken nicht - У чужому очі соломинку бачимо, а у своєму колоди не помічаємо; Wer anderneine Grube gräbt, fällt selbst hinein - Hе рий ямy іншому, сам у неї потрапиш тощо), саме паремії дозволяють скласти уявлення про етнопсихологічні особливості того чи того народу, оскільки мають специфічну образність, яка виникає внаслідок існування постійних асоціативних реалій, характерних для місцевості локалізації етнічної спільноти; мотиваційних розбіжностей (при спільних асоціативних реаліях), також унаслідок неповторного поєднання понять, i відбивають світобачення, властиве кожному народові, відображуючи історичні події, народні традиції тощо. Наприклад: укр. $А$ вже чумак дочумакувався: штанів нема, очкур увірвався; Велике діло - опеньки; Діла на копійку, а балачок на карбованець; Ласкаво просимо мимо наших воріт борщу сьорбати; Не будь Хомою - на те ярмарок; Отакі наші пожитки: ні кожуха, ні свитки; Ченцеві з келії кортить, та ігумен не спить; Чумакові віз ламається - чумак ума набирається; Хвальби повні торби, а в торбах нема нічого; Хто любить піч, тому ворог Січ; Цитьте, жаби, я ваш пан тощо; нім. Freunde in der Not gehn hundert auf ein Lot (дослівно: У біді сотня друзів важить дуже мало); Erziehst du dir 'nen Raben, wird er dir Augen ausgraben (дослівно: Виховаєш собі ворона він тобі очі виклює); Besser ein kleiner Fisch als gar nichts auf dem Tisch (дослівно: Маленька рибка на столі краще, ніж нічого); Mitgegangen, mitgefangen, mitgehangen (дослівно: Мu разом ходили, нас всіх разом піймали, усі разом були повішені); Ноffen und Harren macht manchen zum Narren (дослівно: Сподіватися $i$ чекати - дурним стати); Finden und verhehlen ist so gut wie stehlen (дослівно: Найти й приховати - все одно що вкрасти); Unser Kohl schmeckt wohl (дослівно: Hаша капуста смачна); Nicht jedes Holz gibt einen Bolz (дослівно: Не з кожного дерева можна зробити стрілу); Eine Stunde Schlaf vor Mitternacht ist besser als zwei danach (дослівно: Одна година сну до півночі - краща від двох після); Ein Mann macht keinen Tanz, eine Blume keinen Kranz (дослівно: Один чоловік не складе танцую, із однієї квітки не зробиш вінка); Eine Kuh deckt viel Armut zи 
(дослівно: Одна корова приховує велику бідність); Einem trauen ist genug, keinem trauen ist nicht klug (дослівно: Одному довіряти - добре, нікому не довіряти - нерозумно); Gelb verloren - nichts verloren, Mut verloren - alles verloren (дослівно: Утратиш гроші - нічого не втратиш, утратиш мужність - усе втратиш); Liebe und Verstand gehn selten Hand in Hand (дослівно: Любов і розум рідко йдуть рука в руку); Je mehr Ehr',je mehr Beschwer (дослівно: Чим більше честі, тим більше труднощів) тощо.

Так звані інтернаціональні одиниці поповнили пареміологічний склад тієї чи тієї мови здебільшого шляхом калькування, як-от: укр. Папір витримає і нім. Papier ist geduldig (дослівно: Папір терплячий), які використовують у ситуації, коли хочуть підкреслити: написати можна будь-що і скільки заманеться. І в українській, і в німецькій мовах, як і в ряді інших (рос.: Бумага стерпит), ними послуговуються для пояснення того, чому стало можливим написання чи опублікування чогось нерозумного, недопустимого, неправдоподібного i т. ін. $\mathrm{C}$ калькою $з$ латинського Epistola non erubescit (дослівно: Письмо не червоніс). Вислів належить римському державному діячеві, ораторові і письменнику Марку Цицерону (послання «До друзів»). Так само калькою з латинської мови є пареміологічна одиниця Adler fangen nicht Fliegen (дослівно: Орли мух не ловлять (пор.: лат. Aquila non captat тиscas - Орел мух не ловить; укр. Не царська цее справа; рос. Не царское это дело; Львы мышей не ловят (нім. Löwen fangen keine Mäuse). Інші паремії - укр. У домі повішеного не говорять про мотузку і нім. Im Haus des Gehängten spricht man nicht vom Strick (пор.: poc. В доме повешенного не говорять о веревке) використовують тоді, коли хочуть підкреслити: не варто говорити в присутності когонебудь про те, що йому може бути неприємним, що може сприйнятися як натяк на його слабкості, недоліки, допущені помилки і т. ін. Такими одиницями носії кожної 3 мов послуговуються досить активно, зокрема задля поради змінити неприємну для кого-небудь тему розмови або задля попередження не починати розмову про наболіле, хоч, мабуть, не всі й усвідомлюють те, що паремія має авторство: вислів пов' язують із романом «Дон Кіхот» іспанського письменника Мігеля Сервантеса. Пор. також: Nichts ist ewig (дослівно: Hiщо не вічне); Nichts Neuеs unter der Sonnе (дослівно: Немає нічого нового під сонием); Brot kostet Schweiß (дослівно: Хліб потом дістається); Sagen und Beweisen ist zweierlei (дослівно: Сказати і доказати - дві різні peчi); Kaiser oder nichts (дослівно: Або Цезар, або ніхто) тощо. 
Пареміологічні одиниці кожної з мов будуються за регулярно відтворюваним моделям; їм властива певна гомогенність і граничність; вони хронологічно незмінні: можуть зникнути 3 активного вжитку, але не можуть істотно змінити свого значення; репрезентують ставлення народу до навколишнього світу загалом та оцінку наявних / відсутніх моральних i духовних цінностей, характеризуються стійкістю компонентного складу і здатністю відтворюватися в готовому вигляді. Вони зберігаються в нашій пам'яті і при потребі ми їх видобуваємо звідти. Як свідчить проілюстрований фактичний матеріал, чимало таких усталених конструкцій чітко окреслене національне обличчя. Незважаючи на те, що частина українських і німецьких паремій тяжіє до одних і тих же джерел і їх образна структура може зближуватися, навіть частково перетинатися, кожна 3 мов має свої специфічні елементи, які відображають їх національний колорит. Наприклад: ситуацію, коли акцентують на тому, що особливість людини, іiі звички, справжні почуття i т. ін., як би не прагнули їх змінити, рано чи пізно себе виявляють, українці репрезентують усталеними конструкціями на зразок Вовча натура в ліс тягне; Скільки (як) вовка не годуй, а він усе в ліс дивиться. Німці для цього випадку мають свій оригінальний вислів Die Katze läßt das Mäuschen nicht (дослівно: Кішка не відпустить мишку) (пор. також: укр. Вовк щороку линяє, але вдачі не міняє і нім. Der Fuchs ändert den Balg und bleibt ein Schalk (дослівно: Лисиия міняє шкуру і залишається крутійкою, тобто Лисиия линяє, але вдачі не міняє). Для означення ситуації «досвідчену, бувалу людину не перехитриш, не обдуриш» українці використовують мовний зворот на зразок Старого (стріляного) горобия на полові не обдурии (не зловии); для німців окреслена ситуація асоціюється передусім зі старим лисом - Ein alter Fuchs geht nicht zum zweiten Male in die Falle (дослівно: Старого лиса вдруге не заманиш у пастку). Українська паремія Убити двох зайців одним махом - «одночасно робити дві справи» - співвідноситься 3 німецькомовною Zwei Fliegen mit einer Klappe schlagen (дослівно: Убити двох мух одним ударом); укр. Лякана (полохана) ворона ц̆ куща боїться - «той, хто зазнав труднощів, пережив нещастя, стає надмірно обережним і боїться навіть того, що не приховує в собі небезпеки»- використовується за аналогічної ситуації в німецькій мові у формі Ein beschossener Hase flieht vor jedem Gebüsch (дослівно: Стріляний заєцьь біжить від кожного кущза (пор.: укр. Полохливий заєц̧ь $і$ пенька боїться); укр. 
Уночі всі воли однакові: усі сірі використовується для означення аналогічної ситуації, що й нім. Bei Nacht sind alle Katzen grau (дослівно: Уночі всі кішки сірі). Ситуацію, коли людина розкривається в іiі поведінці, вчинках, конкретних діях, німці характеризують приказкою Am Triller erkennt man die Lerche (дослівно: Жайворонка за cпiвом впізнають). Українці на цей випадок мають свій оригінальний вислів - Видно пана по халявах, що сягає тих часів, коли пани тримали двірську охорону - гайдуків. Гайдуки носили чоботи 3 високими халявами, оздобленими китицями, колір яких визначав сам пан. За барвою цих китиць було легко встановити, у якого пана служить гайдук, тобто можна було розпізнати пана за халявами його охоронців. Зауважимо: 3 часом україномовний синонімічний ряд увиразнюється такими мовними знаками, як Видно птаха по польоту (пор.: рос. Видно птицу по полету), Видно сокола по льоту, а сову з погляду, Пізнати ворону по пір'ю, Орлиний клекіт здалека (з-під хмар) чути; у німецькій мові 3 аналогічним значенням активно функціонують такі паремія, як-от: Den Vogel erkennt man an den Federn (дослівно: Птиця пізнається за пір'ям); Jeder Vogel hat seinen Gesang (дослівно: Кожна птиця має свій голос). Пор. також: Den Fuchs erkennt man am Schwanze (дослівно: Лисицю пізнають по хвосту). Якщо в українському пареміологічному фонді Ворона $\check{u} з а$ море літала, та дурна верталася (пор.: Дурень до Києва, дурень $i$ з Києва; Дурний $і$ в Києві не купить розуму), то в німецькому подібну ситуацію пов' язують з гускою (гусаком) - Flog' ein Gans über's Meer, kam' eine Gans wieder her (дослівно: Гуска за море літала, гускою $i$ поверталася); Es flog ein Gänserich über Rhein und kam als Gickgack wieder heim (дослівно: Гусак за Рейн літав, гусаком і повертався). Пор. також: укр. Осла хоч до Парижа, все одно буде рижий і нім. Affe bleibt ein Affe, werd'er Konig oder Pfaffe (дослівно: Мавпа, хоч король, хоч nin, - yсе одно мавпа) тощо. Аналіз пареміологічних утворень під таким кутом дає наочне уявлення про культурнонаціональне світобачення, про формування та становлення типового образного осмислення світу. Згідно 3 когнітивними підходами, в основі семантики пареміологічної одиниці виділяється концептуальна структура, призначена для представлення стереотипної ситуації, - так званий фрейм (сценарій). Сконденсованим у ньому знанням властива культурно-національна зумовленість, оскільки концепт відображає не просто суттєві ознаки об'єкта, а всі ті, які в певному мовному колективі заповнюються знанням про сутність. 
Паремії кожної з мов - своєрідні мікросвіти, які містять у собі і моральний закон, і здоровий смисл, допомагають ідентифікувати національну свідомість. Це специфічна ознака будь-якої національної мови, де неповторним образом маніфестується дух та своєрідність нації, це «найкультуроносніший компонент мови в дії» (В. Телія). Наприклад: укр. Перший млинець глевкий і нім. Aller Anfang ist schwer (дослівно: Будь-який початок важкий); укр. Бог любить трійцяю і нім. Aller guten Dinge sind drei (дослівно: Усіх хороших речей - по три); укр. Буває, щзо й глухий співає і нім. Auch ein blindes Huhn findet mal ein Korn (дослівно: Навіть сліпа курка іноді знаходить зернятко); укр. Якби свині роги, то б усіх поколола і нім. Вӧsе Kühe haben krumme Hörner (дослівно: Злі корови мають криві роги); укр. Кращче синиця в руках, ніж журавель у небі і нім. Ein Spatz in der Hand ist besser, als eine Taube auf dem Dach (дослівно: Горобецьь в руціi краще, ніж голуб на даху); укр. Одна ластівка весни не робить і нім. Eine Schwalbe macht noch keinen Sommer (дослівно: Одна ластівка ще не робить літа); укр. Сім раз відмір, один відріж і нім. Erst wägen, dann wagen (дослівно: Спериу обдумати, потім відважитися). У внутрішній формі більшості 3 них містяться такі смисли, які надають їм культурно-національного колориту. Значення подібних паремій можна інтерпретувати 3 позицій ціннісних настанов, які притаманні ментальності певної нації. Засобом втілення культурно-національної специфіки слугує образне підгрунтя. Пареміологічні одиниці являють собою сукупність культурної інформації, дозволяють сказати більше, економлячи мовні засоби, та в той же час добираються до глибин народного духу, культури (наприклад, укр. Гарний півень жирним не буває; Миша не одну діру до хати має; Повадиться глечик по воду ходити, там йому й голівку положити; Усього спізнати мусиш на віку: $і$ по спині, і по боку; Як загнав на слизьке, про підкови згадав; нім. Glück und Glas, wie leicht bricht das (дослівно: Щастя і скло, як же вони легко б'ються); Wer zufrieden ist, ist glücklich (дослівно: Хто задоволений, той щзасливий); Keck holt die Braut weg (дослівно: Сміливий і наречену вкраде); Des einen Tod, des andern Brot (дослівно: Смерть одного - хліб для іншого); Was man spart vom Mund', fressen Katz' und Hund (дослівно: Те, щуо відривають від свого рота, з'їять кішка і собака); Achtung ist besser als Gold (дослівно: Увага краша як золото); Adler brüten keine Tauben (дослівно: $B$ орлів голуби не родяться); Den Adler fliegen lehren (дослівно: Учити орла літати) тощо. У глибинних зв'язках таких стійких словесних комплексів 
закодована інформація про світ відповідної країни, іiі історію, психологічний стереотип народу, спосіб життя на різних етапах його розвитку і т. ін.

Будучи невід'ємним компонентом духовної культури, пареміологіяні одиниці й української, i німецької мов водночас демонструють близькістю їх носіїв в оцінках тих чи тих життєвих ситуацій, про що свідчать передусім так звані абсолютні еквіваленти, тобто одиниці, тотожні і за формою, і за змістом. Наприклад: Alles vergeht, Wahrheit besteht (дослівно: Усе минеться, правда зостанеться); Alles zu seiner Zeit (дослівно: Усьому свій час); Andere Zeiten, andere Sitten (дослівно: Інші часи, інші звичаі); Andrer Tag, andre Plag' (дослівно: Інший день, інші клопоти); Kraft, die nicht wirkt, erschlafft (дослівно: Незадіяна сила слабне); Ein guter Plan ist halb getan (дослівно: Гарний план - половина виконаної справи); Frisch begonnen ist halb gewonnen (дослівно: Гарно почате - наполовину вигране); Die Zeit ist der beste Arzt (дослівно: Час - найкращий лікар); Zeit ist der beste Ratgeber (дослівно: Час - найкращий порадник); Zeit ist Geld (дослівно: Чac - ие гроші); Den Freund erkennt man in der Not (дослівно: Друзі пізнаються в біді) тощо. Такі пареміологічні одиниці є емотивними знаками, що забезпечують як внутрішнє, так і зовнішнє (міжкультурне) спілкування, зокрема й на емоційному рівні. А це означає: загальний емоційний простір людства передбачає існування загального (інваріантного) емоційного смислового поля, яке кодується i відтворюється у відповідних (лексичних, фразеологічних, пареміологічних) знаках мови.

Деякі аналізовані одиниці можна назвати абсолютними еквівалентами лише умовно, оскільки в тій, чи тій національній мові функціонують паремії, що демонструють специфічні національні риси, як-от: Alles oder Nichts (дослівно: Усе або нічого (пор.: Або пан або пропав); Alter ist kein werter Gast (дослівно: Cmapicmь не гість); Alter ist ein schweres Malter (дослівно: Cтарість - тяжка ноша (пор.: Cmapicmь не радість); Andre Stadhen, andre Mdchen (дослівно: Iнші міста, інші дівчата (пор.: Інші краӥни, інші звичаі); Einer ist keеnеr (дослівно: Один все одно, щзо нікого); Ein Mann, kein Mann (дослівно: Один чоловік - жодного чоловіка (пор.: Один у полі не воїн); Was man nicht im Kopf hat, muss man in den Beinen haben (дослівно: Як немає в голові, ноги мусять відповідати (пор.: За дурною головою то й ногам нема спокою); Ein alter Freund ist zwei neue wert (дослівно: Старий друг кращий за двох нових (пор.: Для приятеля нового не иурайся старого; Над друга старого нема в світі нікого) тощо. 
Переконливою видається думка про те, що в пареміологічному розмаїтті національних мов переважають не універсальні, а специфічні риси, зумовлені різним світобаченням, світосприйняттям, інтерпретацією навколишньої дійсності: нім. Eulen nach Athen tragen (дослівно: Нести сов до Афін (укр. Їхати до Криму зі своєю сіллю; poc. Ехать в Тулу со своим самоваром); In Rom tu, wie Rom tut (дослівно: У Римі веди себе, як римлянин (укр. До чужого монастиря зі своїм статутом не пхайся; рос. В чужой монастырь со своим уставом не ходят). Пор. також: укр. Гарна дівка, як засватана; Тоді його ціну бачиш, як утратиш - «жартівливий натяк на чию-небудь легковажність» і нім. Hat die Kuh den Schwanz verloren, so merkt sie erst, wozи er gut gewesen (дослівно: Загубить корова хвоста, тодi зрозуміє, для чого він потрібен); укр. Старий кінь (віл) борозни не nсує; Старий віл з борозни не зверне - «стара, досвідчена людина не зіпсує те, за що береться» і нім. Alter Hund macht gute Jagd (дослівно: Старий собака робить добрим полювання); укр. Корова, яка багато реве, мало молока дає - «про того, хто лише на словах має певні досягнення, а насправді від нього мало користі» і нім. Huhner, die viel gackern, legen wenig Eier (дослівно: Кури, які багато кудкудахкають, мало яєць несуть); укр. Нате ци мій глек на капусту, щоб $і$ я була Настя (Хівря) - «говориться як докір при невиправданому прагненні долучитися до інших» і нім. Gesummt ist auch gesprochen (дослівно: Продзижчав - теж сказав). Зауважимо: образне наповнення семантично близьких українських і німецьких паремій може частково збігатися, зокрема йдеться насамперед про узагальнено-метафоричне наповнення суб'єкта дії: укр. Не бійся собаки, щзо бреше, а тісї, щзо лащиться і нім. Bange Hunde bellen viel (дослівно: Боязкі собаки брешуть багато) - «не варто боятися людини, яка вочевидь висловлює свої погрози, більшу небезпеку становлять ті, які втерлися в довіру» (пор.: Ehrlicher Feind ist besser als falscher Freund (дослівно: Чесний ворог кращий за фальшивого друга). Такий зоонімічний образ у різних семантичних (i, відповідно, структурних) модифікаціях доволі часто маніфестується в пареміологічних фондах обох мов (пор.: нім. Schweigender Hund beißt am ersten (дослівно: Мовчазний собака спідтишка кусає); нім. Alte Hunde haben stumpfe Zähne (дослівно: У старого собаки тупі зуби) і т. ін. Особливо виразними є ті пареміологічні одиниці, у яких так званий образний зоокомпонент $€$ відмінним, наприклад: українські паремії на зразок Вітер віє, собака бреше; Вітер повіє, а собака брехне; Собака бреше, а караван іде; 
Собака гавкає (бреше), а вітер несе (носить); Собака гавкає, а мажі йдуть; Пес бреше, дош чеше, а вітер далі несе; Пси виють, а місяиь cвiтuть використовуються для означення тієї самої ситуації, що й німецька Was ein Esel von mir spricht, das acht' ich nicht (дослівно: Te, щзо мені говорить осел, я не беру до уваги), тобто для вираження ставлення до пліток, пустослів'я - «не варто звертати увагу на чиїнебудь слова, докори, чутки, розмови». У таких пареміологічних одиницях закодовано відповідну культурну інформацію, декодування якої дає змогу стверджувати: обрана матеріальна форма вираження дозволяє економити мовні засоби, забезпечуючи при цьому максимальну виразність змісту. Пор.: нім. Falken und Tauben mu $\beta$ man nicht zusammensperren (дослівно: Сокола i голуба в одну клітку не сажають) й укр. Два ведмеді в одному барлозі не живуть; Два коти в одному мішку (на одному салі) не помиряться - «суперники разом не вживаються»; нім. Man hält seine eigenen Gänse für Schwäne (дослівно: Свій гусак здається лебедем) й укр. Кожна лисичя свій хвостик хвалить - «кожному найкращий той, хто є рідний, близький»; нім. Man schlägt nicht Mücken mit Keulen tot (дослівно: Комарів дубинками не б'ють) й укр. Із гармат по горобиях не стріляють - «про невідповідність витрачених зусиль меті та бажаним результатам»; нім. Mit Speck fängt man Mäuse (дослівно: Muші на сало ловляться) й укр. Мухи на мед злітаються - «завжди є щось таке, що слугує принадою для когось»; нім. Das Pferd will wohl den Hafer, aber nicht den Sattel (дослівно: Любить кінь овес, та сідла не любить) й укр. Ласа кішка до риби, та в воду лізти не хоче - «треба не лише користуватися чужими результатами, але й докладати зусилля принаймні для задоволення власних життєво важливих потреб» тощо. Чимало німецьких паремій, у структури яких наявний той чи той зоокомпонент, мають українські відповідники, у яких образна основа жодним чином не пов'язується 3 тваринним світом. Те саме простежується й на прикладі українсько-німецьких пареміологічних паралелей, як-от: нім. Großer Vogel, großes Nest (дослівно: Великій птиці - велике гніздо) й укр. Великому кораблю - велике плавання «надзвичайну людину чекає і велика плідна діяльність»; укр. Курчат восени рахують і нім. Lobe den Flachs nicht, bevor das Leinen gewoben ist (дослівно: Не хвали льон, поки не зробив полотна) - «про щонебудь варто судити лише за кінцевим результатом»; укр. Повів коня кувати, як кузня згоріла і нім. Die Spritzen kommen, wenn das Haus abgebrannt ist (дослівно: Приїхали пожежники, як хата згоріла) - 
«про непередбачливу людину, яка пізно спохватилася» (пор.: укр. мудрий по шкоді; рос. Задним умом крепок).

Кількість українських i німецьких паремій, організованих навколо слів-компонентів, що належать до тваринного світу, зокрема й зооніма собака (der Hund), є досить значною. Наприклад: укр. Бійся не того собаки, щуо бреше, а того, щуо лащчиться; Вдача собача, натура вовча; Де свої собаки кусаються, там хай чужі не пхаються; До собаки підходь ззаду, а до коня спереду; Звик собака за возом бігти - побіжить $і$ за саньми; 3 жиру собака біситься; 3 собакою дружи, а палицю в руках держи; I собака чує, хто його годує; Кожний пес на своїм смітті пан; Кожний пес перед своїм порогом сміливий; Він, як собака на сіні: $і$ сам не гам, $і$ комусь не дам; Не для пса ковбаса, не для кота сало; Не дражни собаку, так і гавкать не буде; Не тоді собак годують, як на полювання йдуть; Собака бреше, акінь іде; Як собаку годують, так він $і$ гавкає; Як не вертись, собако, а хвіст ззаду і т. ін. та нім. Wie ein toter Hund zum Bellen (пор.: укр. Толку, як з козла молока); Den Hund an eine bratwurst binden (пор.: укр. Пустили цуапа в капусmy); Der Hund ist freudig auf seinem Hofe (пор.: укр. Кожний пес на своєму подвір'̈̈ гордий); Wenn der Hund unten liegt, beißen ihn alle Hunde (пор.: укр. Підстреленого сокола $i$ ворони б'ють); Wo der Hund aufs Kissen kommt, will er mit im Bette liegen (пор.: укр. Пусти собаку під стіл, а він дереться на стіл; Пусти свиню за стіл, вона й ратиц̧і на стіл); Am Riemen lernt der Hund Leder kauen (пор.: укр. Украдеш голку, а потім коровку); Getroffener Hund bellt (пор.: укр. На злодієві шапка горить); Alte Hunde sind schwer bändig zи machen (пор.: укр. Старого собаку не привчии до ланцяюга); Bande Hunde bellen viel (Hunde, die viel bellen, beißen nicht) (пор.: укр. Бійся пса не того, щуо гавкає, а того, щуо лащчиться; Який собака багато бреше, мало кусає); Begossene Hunde fürchten das Wasser (пор.: укр. Битому собаиі кия не показуй); Bissige Hunde fahren in jeden Stein (пор.: укр. Дурний собака і на хазяїна бреше); Bissige Hunde habeh zerrissene Ohren (Böser Hund - zerrissen Fell) (пор.: укр. Пустився в бійку - чуба не жалій); Stumme Hunde und stille Wasser sind gefährlich (пор.: укр. Tuха вода греблю рве); Viele Hunde sind des Hasen Tod (пор.: укр. Де багато собак, там зайцю смерть); Zwei Hund' an einem Bein kommen selten überein (пор.: укр. Два ведмеді в одному бар лозі не живуть); Bösem Hund gehört ein Knittel (пор.: укр. По собаці й иіпок); Wenn man den Hund schlagen will, findet man bald einen Stecken (пор.: укр. Хто хоче вдарити, той кия знайде); Schlafenden Hund soll man 
nicht wecken (пор.: укр. Не чіпай лихо, коли воно спить); Wer mit Hunden zu Bett geht, steht mit Flöhen auf (пор.: укр. Хто з псами лягає, той з блохами встає); Wer nach jedem bellenden Hunde werfen will, mи $\beta$ viele Steine aufheben (пор.: укр. Великої треба хусти, щуоб зав'язати людям усти) тощо. Причому, як свідчить проілюстрований вище фактичний матеріал, німецько-українські пареміологічні паралелі, як і українсько-німецькі, будучи семантично близькими, здебільшого відрізняються узагальнено-метафоричними образами. Серед них спостерігаємо одиниці, досить різнорідні за структурною організацією, за пізнавальною роллю i за ситуацією вживання. Здебільшого саме пареміологічні одиниці з зоокомпонентами є, так би мовити, двопланові: 3 одного боку, вони актуалізують прямий план змісту, що дає змогу сприйняти його буквально, 3 іншого, репрезентують алегоричний (метафорично-образний) план змісту, який дебуквалізує висловлення: воно набуває узагальненотипізуючого значення.

Цілком закономірно, що, функціонуючи передусім як оцінні мовні знаки, пареміологічні одиниці і німецької, й української мов сконцентровують увагу на людині, їі оточенні, рисах характеру і т. ін. Цим, власне, і зумовлена систематизація пареміологічних утворень за відповідними семантичними особливостями, лексико-семантичними групами. На цій підставі паремії об'єднуються переважно за так званими тематичними групами, як-от: прислів'я про дружбу, про хліб, про працю, про розум, про здоровий спосіб життя і т. ін.

Такі усталені мовні звороти репрезентують споконвічні людські цінності, ставлення до батьківщини, родини, одруження і т. ін., як-от: укр. Хоч за вола, аби дома не була; Хоч без зубів $і$ в однім оку, аби цьвого року; Старій кобилі не брикати, сивій бабі не цілувати; Не мав лиха, так оженився; Не женився - не журився, оженився зажурився; Чоловік і жінка - то одна спілка; Муж іжона - то одна caтана і нім. Mein Nest ist das best' (дослівно: Своє гніздо найкраще); Ost und West, daheim das Best (дослівно: Схід чи захід, а вдома краще); Ein alter Mann, der freit, ist nicht gescheit (дослівно: Нерозумний той, хто на старості жениться); Junge Frau und aller Mann ist ein trauriges Gespann (дослівно: Молода дружина $i$ старий чоловік жалюгідна упряжка); Mann und Weib sind ein Leib (дослівно: Чоловік $i$ дружина - одна плоть) тощо.

У пареміологічній системі обох мов чітко окреслена роль дружини як друга, порадниці, господині: укр. Жінка, як лоза: куди 
схочеш, похилиш; Жінка, як жилка: коли схочеш, потягнеш; Ліпше чорта тримати, ніж ледачу жінку мати; Без хазяїна двір, а без хазяйки хата плаче; Дім держсться не на землі, а на жінці; Жінка за три кутки хату держить, а чоловік за один; Жінка чоловікові подруга, а не прислуга; Нема вірнішого приятеля, як добра жінка; Од господаря повинно пахнути вітром, а од господині - димом; Жіноча річ коло припічка і нім. Mann ohne Weib, Haupt ohne Leib (дослівно: Чоловік без жінки, як голова без тіла); Ein Mann ohne Frau ist ein Baum ohne Laub und Zweige (дослівно: Чоловік без жінки, щзо дерево без крони); Wo die Frau wirtschaftet, wächst der Speck am Balken (дослівно: Де дружина господиня, там і балки салом обростають); Mit den Ohren such dir eine Frau, nicht mit den Augen (дослівно: Дружину вибирай не очима, а вухами) тощо; засвідчені стосунки батьків та дітей: укр. Від малих дітей голова болить, а від великих серие; Годуй діда на печі, бо й сам будеш там; Годуй сина для себе, а дочку - для людей; Діти - до часу, а онуки - до смерті; Добрі діти батькам вінець, а злі діти - кінець; Добрі діти доброго слова послухають, а лихі - й дрючка не бояться; Малі діти не дають спати, а великі - дихати; Шануй батька й неньку, то буде тобі скрізь гладенько і нім. Es ist besser, das Kind weine denn die Mutter (дослівно: Краще дитині плакати, ніж матері); Barmherzige Mutter zieht lausige Kinder (дослівно: У жалісливих матерів жалюгідні діти); Kleine Kinder drücken die Knie, große das Herz (дослівно: Від малого дитяти болять коліна, від великого - серие); Kleine Kinder treten der Mutter auf die Schürze, große aufs Herz (дослівно: Малі діти матері на пелену наступають, великі - на серие); Kleine Kinder, kleine Sorgen, große Kinder, große Sorgen (дослівно: Малі діти - малі клопоти, великі діти - великі клопоти) тощо; утверджується добро і засуджується зло (у широкому витлумаченні): укр. Добре з добрим $i$ коло стовпа постоять; Не чини лихого, не бійся нікого; Май добру натуру, не приймеш кари на шкуру; Хто чисте сумління має, той спокійно спати лягає; Чеснота і того гріє, хто без кожуха у мороз; Правда і в морі не втоне і нім. Gesunder Mann, reicher Mann (дослівно: Здоровий чоловікбагатий чоловік); Jugend wild, Alter mild (дослівно: Молодість буйна, старість коротка); Was drei wissen, erfahren bald dreißig (дослівно: Що знають троє, знатимуть тридиять); Nach Faulheit folgt Krankheit (дослівно: За лінощами по n'ятах хвороба ide); Ein kluger Kopf hat einen geschlossenen Mund (дослівно: У розумної голови рот закритий); Unter den Blinden ist der Einäugige König (дослівно: Між сліпими $i$ 
кривий у пошані); Verstand läßt sich nicht eintrichtern (дослівно: Розуму палицею не вбгаєш); Fleiß ist des Glückes Vater (дослівно: Труд батько щастя); Der Fleißige macht aus einem Tage zwei (дослівно: Працелюб із одного дня два робить) тощо. Усі вони мають здебільшого моралізаторське призначення, відштовхуються від загальнолюдського уявлення про хороше і погане, добро і зло, про позитивні та негативні якості, риси характеру тощо. На жаль, обмежений обсяг статті не дозволяє нам детальніше зупинитися на специфічних рисах паремій відповідних тематичних груп. Це вже проблема іншої наукової розвідки, що передбачатиме й лексикографічний аспект.

Наближення до глибинного змісту етнокультурної специфіки пареміологічного знака й усебічне дослідження його прагматичного змісту та конотації можливе через концептуальний аналіз. Погляд на компоненти пареміологічної одиниці як на концепти вимагає передусім декодування етнокультурної інформації, зокрема й урахування етимологічного аналізу, хоч окреслене завдання не 3 легких.

Насамкінець зауважимо: аналізовані усталені мовні звороти, беззаперечно, є важливим джерелом фонових знань носіїв тієї чи тієї мови, невід'ємною частиною будь-якої національної культури, бо вирізняють людину як представника певної національно-культурної спільноти, а відтак потребують більш глибокого і детального вивчення щодо їх культурно зумовлених, національних (специфічних) ознак. Адже саме в пареміях відбивається пізнавальний загальнолюдський i національний досвід.

\section{Література}

1. Голубовська I. О.Етнічні особливості мовних картин світу : [монографія]/ І. О. Голубовська. - [2-е вид.]. - К. : Логос, 2004. - 284 с.

2. Жайворонок В. В. Українська етнолінгвістика : деякі аспекти досліджень / В. В. Жайворонок // Мовознавство. - 2001. - № 5. - С. 48-63.

3. Жданова В. В. Пословицы и поговорки как источник изучения русского культурно-языкового сознания / В. В. Жданова // Культурные слои во фразеологизмах и в дискурсивных практиках / Отв. ред. В. Н. Телия. - М. : Языки славянской культуры, 2004. - С. 151-159. - (Studia philologica).

4. Немецкие пословицы и поговорки // Электронная версия : Режим доступа : http://aphorismlist.com/poslovica.php?page=german1\&tkposlovica

5. Пермяков Г. Л. Основы структурной паремиологии / Г. Л. Пермяков. - М. : Наука, 1988. - 213 с.

6. Прислів'я та приказки : Людина. Родинне життя. Риси характеру / Упорядник: М. М. Пазяк. - К. : Наукова думка, 1990. - 528 с.

7. Телия В. Н. Культурно-языковая компетенция: ее высокая вероятность и 
глубокая сокровенность в единицах фразеологического состава языка / В. Н. Телия // Культурные слои во фразеологизмах и в дискурсивных практиках / Отв. ред. В. Н. Телия. - М. : Языки славянской культуры, 2004. - С. 19-30. - (Studia philologica).

8. Українські приказки, прислів’я і таке інше / Уклав М. Номис / Упоряд., приміт. та вступна стаття М. М. Пазяка. - К. : Либідь, 1993. - 768 с.

9. Deutsch-ukrainisches phraseologisches Wörterbuch / von W. I. Gawris und O. P. Prorotschenko. - K. : Radjanska schkola, 1981. - Band I (A - K). - 416 s.; Band II $(\mathrm{L}-\mathrm{Z}) .-382 \mathrm{~s}$.

Стаття надійшла до редакції 31.05.2012 p. 